\title{
HUBUNGAN LOCUS OF CONTROL DENGAN KOMITMEN ORGANISASI PERAWAT DI RUANG RAWAT INAP RUMAH SAKIT
}

\author{
Rachmawati Rachim ${ }^{1}$, Abd. Rahman Kadir ${ }^{2}$, Werna Nontji ${ }^{3}$ \\ ${ }^{1}$ Jurusan Keperawatan Poltekkes Kemenkes Mamuju, \\ ${ }^{2}$ Fakultas Ekonomi dan Bisnis Universitas Hasanuddin, \\ ${ }^{3}$ Program Studi Ilmu Keperawatan Universitas Hasanuddin
}

\begin{abstract}
Nurses' organizational commitment can be affected by characteristics of individuals and organizations locus of control is one domain of personality. This study aimed to analyze the relationship between locus of control with organizational commitment. This research was an analytic survey with cross-sectional study. The samples were implementer nurses in inpatient rooms as many as 63 people selected using total sampling method. The data were obtained using questionnaires by respondents. Chi-square test was used to test the relationship of locus of control with nurse organizational commitment. The results of the research indicate that there is a significant relationship between locus of control with organizational commitment nurses $(p=0.003)$. Advised to consider the type of locus of control in placing nurses, especially afectif commitment and normative, and further research on organizational variables to strengthen the study.
\end{abstract}

Keyword: Nurse, locus of control, organizational commitment.

\section{PENDAHULUAN}

Sumber daya manusia (SDM) merupakan aspek yang sangat penting dalam menentukan produktivitas organisasi. Kinerja karyawan melalui kualitas layanan merupakan suatu keharusan dan strategi yang harus dikembangkan oleh organisasi. Apabila pelayanan yang diberikan melalui kinerja karyawan mampu memuaskan konsumen, maka konsumen akan menjadi pelanggan yang loyal sehingga dapat mendorong kinerja organisasi.

Salah satu faktor yang membuat karyawan bekerja secara menyenangkan dan memuaskan adalah adanya komitmen organisasi dimana seseorang itu bekerja (Greenberg et al., 1997 dalam Hidayat, 2011). Komitmen organisasi merupakan sikap yang merefleksikan loyalitas karyawan terhadap organisasi dan proses berkelanjutan dimana anggota organisasi mengekspresikan perhatiannya terhadap organisasi dan keberhasilan serta kemajuan yang berkelanjutan sehingga nantinya anggota organisasi berusaha mewujudkan keberhasilan dari tujuan organisasi (Luthans, 2006).

Menurut Robbins (2005), bahwa locus of control merupakan variable penting yang dapat menjelaskan perilaku manusia dalam organisasi. Perawat dengan internal locus of control menganggap bahwa keluhan klien dan keluarganya terhadap pelayanan di rumah sakit merupakan tanggung jawabnya, sehingga mereka berusaha memberikan pelayanan yang terbaik kepada kliennya. Sebaliknya perawat dengan eksternal locus of control menganggap setiap kejadian tidak ada hubungannya dengan perilakunya tetapi disebabkan oleh factor di luar kendalinya seperti nasib, takdir atau penguasa; sehingga mereka sering menyalahkan lingkungan sekitarnya dan tidak berusaha memperbaiki keburukan (Adolfina, 2012).

Rotter (1966) berpendapat, locus of control merupakan persepsi individu terhadap sumber-sumber yang mengontrol kejadian dalam kehidupannya. Internal locus of control mengacu kepada persepsi bahwa kejadian apapun baik yang positif maupun yang negative merupakan konsekuensi dari perbuatan diri sendiri atau di bawah pengendalian diri. Sedangkan eksternal locus of control mengacu kepada persepsi bahwa suatu kejadian baik yang positif maupun yang negative tidak berhubungan langsung dengan tindakan diri sendiri dan berada di luar control dirinya. Namun seseorang tidak memiliki Internal maupun eksternal locus of control secara jelas, karena locus of control merupakan variable kontinyu dan dinamis dan dapat bervariasi situasional, sehingga individu diklasifikasikan sepanjang spectrum dari sangat internal ke sangat eksternal. (Adolfina, 2012)

Hasil penelitian (Chen \& Wang, 2007), internal locus of control berasosiasi dengan affective dan normative commitment yang 
tinggi, sedangkan external locus of control berasosiasi dengan continuance commitment yang tinggi. Adapun tujuan dari penelitian ini adalah untuk menganalisis hubungan locus of control dengan komitmen organisasi.

\section{BAHAN DAN METODE}

\section{Desain Penelitian}

Jenis penelitian ini adalah Survei Analitik, Cross sectional dengan cara pendekatan, observasi atau pengumpulan data sekaligus pada suatu saat (point time approach) artinya tiap subyek penelitian hanya diobservasi sekali saja (Notoatmodjo, 2010). Rancangan ini dimaksudkan untuk menganalisis hubungan locus of control dengan komitmen organisasi.

\section{Lokasi dan Waktu Penelitian}

Penelitian ini dilaksanakan di ruang perawatan bedah, perawatan penyakit dalam, perawatan anak, perawatan isolasi dan perawatan kelas 1 di Rumah Sakit Umum Daerah Provinsi Sulawesi Barat, pengambilan sampel dilakukan selama 3 minggu sejak tanggal 11 sampai 28 Pebruari 2013.

\section{Populasi, Sampel dan Sampling}

Populasi penelitian ini adalah seluruh perawat di ruang perawatan penyakit dalam, perawatan bedah, dan ruang perawatan perawatan isolasi dan perawatan kelas 1 di Rumah Sakit Umum
Daerah Provinsi Sulawesi Barat sebanyak 63 orang yang ditemui selama penulis melakukan penelitian. Sampel dalam penelitian ini, sebanyak 63 orang yang dipilih secara total sampling dan telah memenuhi kriteria inklusi.

\section{Instrumen Penelitian}

Sebagai alat pengumpulan data yang digunakan adalah kuesioner dalam bentuk pernyataanpernyataan yang berkaitan dengan karakteristik demografi responden, locus of control dan komitmen organisasi. Kuesioner yang penulis gunakan adalah kuesioner baku yaitu: locus of control diambil dari The Work Locus of Control Scale (WLCS) yang dikembangkan oleh Spector (1988) dan komitmen organisasi diambil dari Organizational Commitment Questinare (OCG) Meyer dan Allen (1991) dalam (Adolfina, 2012).

\section{Pengolahan dan Analisis Data}

Pengolahan data dengan menggunakan bantuan perangkat lunak komputer. Kegiatan ini dilakukan melalui beberapa tahapan yakni editing, coding, prosesing atau memasukan data (entry data) dan cleaning. Setelah itu data dianalisis secara univariat dan bivariat digunakan uji statistik chi-square, dengan nilai kemaknaan $p<0,05$.

\section{HASIL PENELITIAN}

Tabel 1. Karakteristik Demografi Responden di Ruang Rawat Inap RSUD Provinsi Sulawesi Barat Tahun 2013

\begin{tabular}{lcc}
\hline \multicolumn{1}{c}{ Karakteristik } & $\mathbf{n}$ & $\mathbf{\%}$ \\
\hline Umur (tahun) & 34 & \\
$21-25$ & 29 & 54.0 \\
$25-30$ & & 46.0 \\
Jenis Kelamin & 7 & 11.1 \\
$\quad$ Laki-laki & 56 & 88.9 \\
$\quad$ Perempuan & & \\
Status Perkawinan & 36 & 57.1 \\
$\quad$ Belum Kawin & 27 & 42.9 \\
Kawin & & \\
Tingkat Pendidikan & 60 & 95.2 \\
DIII + S1 Kep & 3 & 4.8 \\
S1 Kep + Ners & & \\
Masa Kerja (tahun) & 59 & 93.7 \\
Baru (<5) & 4 & 6.3 \\
$\quad$ Lama ( $\geq 5$ ) & & \\
Status Kepegawaian & 40 & 63.5 \\
PNS & 23 & 36.5 \\
Non PNS & 63 & 100 \\
$\quad$ Jumlah & & \\
\hline
\end{tabular}


Tabel 1 terlihat bahwa sebagian besar responden berusia antara 21 - 25 tahun yaitu sebanyak 34 orang (54\%), jenis kelamin adalah perempuan sebanyak 56 orang $(88,9 \%)$, status perkawinan terbanyak belum menikah sebanyak 36 orang $(57,1 \%)$, pendidikan sebagian besar
Diploma III yaitu sebanyak 60 orang $(95,2 \%)$, masa kerja sebagian besar antara $1-5$ tahun sebanyak 61 orang $(96,8 \%)$, dan status kepegawaian terbanyak adalah pegawai negeri sipil (PNS) sebanyak 40 orang $(63,5 \%)$.

Tabel 2. Hubungan Locus of Control dengan Komitmen Organisasi

\begin{tabular}{ccccccccc}
\hline & \multicolumn{4}{c}{ Komitmen Organisasi } & \multicolumn{2}{c}{ Total } & p \\
Locus of Control & \multicolumn{2}{c}{ Tinggi } & \multicolumn{2}{c}{ Rendah } & & & \\
& $\mathbf{n}$ & $\boldsymbol{\%}$ & $\mathbf{n}$ & $\boldsymbol{\%}$ & $\mathbf{n}$ & $\%$ & \\
\hline Internal & 37 & 80.4 & 9 & 19.6 & 46 & 100 & \\
Eksternal & 7 & 41.2 & 10 & 58.8 & 17 & 100 & 0.003 \\
Total & 44 & 69.8 & 19 & 30.2 & 63 & 100 & \\
\hline
\end{tabular}

Tabel 2 menunjukkan, sebanyak 80,4\% responden dengan kecenderungan ke arah internal locus of control memiliki komitmen yang tinggi dan $19,6 \%$ responden dengan kecenderungan ke arah internal locus of control memiliki komitmen yang rendah, sementara $58,8 \%$ perawat dengan external locus of control memiliki komitmen yang rendah dan 41,2\% responden dengan external locus of control memiliki komitmen yang tinggi. Hasil uji chisqure menunjukkan hubungan yang bermakna antara locus of control dengan komitmen organisasi $(p=0,003)$.

Tabel 3. Hubungan Locus of Control dengan Komitmen Afektif Perawat Pelaksana di Ruang Rawat Inap RSUD Provinsi Sulawesi Barat Tahun 2013

\begin{tabular}{ccccccccc}
\hline & \multicolumn{4}{c}{ Komitmen Afektif } & \multicolumn{3}{c}{ Total } & p \\
Locus of Control & \multicolumn{2}{c}{ Tinggi } & \multicolumn{2}{c}{ Rendah } & \multicolumn{2}{c}{} \\
& $\mathbf{n}$ & $\boldsymbol{\%}$ & $\mathbf{n}$ & $\boldsymbol{\%}$ & $\mathbf{n}$ & $\boldsymbol{\%}$ & \\
\hline Internal & 40 & 87.0 & 6 & 13.0 & 46 & 100 & \\
Eksternal & 13 & 76.5 & 4 & 23.5 & 17 & 100 & 0.438 \\
Total & 53 & 84.1 & 10 & 15.9 & 63 & 100 & \\
\hline
\end{tabular}

Berdasarkan tabel 3 dapat terlihat bahwa tidak ada hubungan locus of control dengan komitmen afektif perawat pelaksana, dengan nilai hasil uji Fisher's p $=0.438$.
Artinya bahwa baik individu dengan internal maupun eksternal berpotensi memiliki keterikatan secara emosional dengan organisasi.

Tabel 4. Hubungan Locus of Control dengan Komitmen Normatif Perawat Pelaksana di Ruang Rawat Inap RSUD Provinsi Sulawesi Barat Tahun 2013

\begin{tabular}{|c|c|c|c|c|c|c|c|}
\hline \multirow{3}{*}{ Locus of Control } & \multicolumn{4}{|c|}{ Komitmen Normatif } & \multirow{2}{*}{\multicolumn{2}{|c|}{ Total }} & \multirow{3}{*}{$\mathbf{p}$} \\
\hline & \multicolumn{2}{|c|}{ Tinggi } & \multicolumn{2}{|c|}{ Rendah } & & & \\
\hline & $\mathbf{n}$ & $\%$ & $\mathbf{n}$ & $\%$ & $\mathbf{n}$ & $\%$ & \\
\hline Internal & 39 & 84.8 & 7 & 15.2 & 46 & 100 & \\
\hline Eksternal & 12 & 70.6 & 5 & 29.4 & 17 & 100 & 0.279 \\
\hline Total & 51 & 81.0 & 12 & 19.0 & 63 & 100 & \\
\hline
\end{tabular}

Berdasarkan tabel 4 dapat terlihat bahwa tidak ada hubungan locus of control dengan komitmen normatif perawat pelaksana, dengan nilai hasil uji Fisher's p $=0.279$. Artinya bahwa baik individu dengan internal maupun eksternal berpotensi memiliki 
komitmen karena merasa adanya kewajiban

terhadap organisasi.

Tabel 5. Hubungan Locus of Control dengan Komitmen Berkelanjutan Perawat Pelaksana di Ruang Rawat Inap RSUD Provinsi Sulawesi Barat Tahun 2013

\begin{tabular}{ccccccccc}
\hline \multirow{2}{*}{ Locus of Control } & \multicolumn{4}{c}{ Komitmen Berkelanjutan } & \multicolumn{2}{c}{ Total } & \multirow{2}{*}{ Tinggi } & \multicolumn{2}{c}{ Rendah } & \multicolumn{2}{c}{} & \multirow{2}{*}{} \\
& $\mathbf{n}$ & $\mathbf{\%}$ & $\mathbf{n}$ & $\boldsymbol{\%}$ & $\mathbf{n}$ & $\boldsymbol{\%}$ & \\
\hline Internal & 19 & 41.3 & 27 & 58.7 & 46 & 100 & \\
Eksternal & 3 & 17.6 & 14 & 82.4 & 17 & 100 & 0.080 \\
Total & 22 & 34.9 & 41 & 65.1 & 63 & 100 & \\
\hline
\end{tabular}

Berdasarkan tabel 5 dapat terlihat bahwa tidak ada hubungan locus of control dengan komitmen berkelanjutan perawat pelaksana, dengan nilai hasil uji Chi-square $\mathrm{p}=$ 0.080. Artinya bahwa baik individu dengan internal maupun eksternal memiliki komitmen bukan karena tidak ada pilihan lain untuk bekerja dan kerugian yang ditimbulkan jika meninggalkan organisasi.

\section{PEMBAHASAN}

Penelitian ini menunjukkan bahwa terdapat hubungan locus of control dengan komitmen organisasi. Sebagian besar perawat $(80,4 \%)$ yang memiliki kecenderungan internal locus of control juga memiliki komitmen organisasi yang tinggi. Hal ini membuktikan bahwa ada hubungan locus of control dengan komitmen organisasi. Orang yang memiliki kecenderungan internal menganggap bahwa keberhasilan itu disebabkan oleh usaha dan kerja kerasnya.

Menurut teori yang dikembangkan oleh (Rotter, 1966), locus of control memiliki hubungan besar dengan perilaku, dimana seorang individu menerima kejadian-kejadian sebagai bagian dari perilaku atau karakteristiknya sendiri.

Perilaku kerja dapat dijelaskan dengan menggunakan locus of control, yaitu apakah karyawan merasa bahwa hasil kerja mereka dikendalikan secara internal atau eksternal. Karyawan yang termasuk kelompok internal control, akan merasa bahwa secara personal mereka dapat mempengaruhi kinerjanya melalui kemampuan, keahlian dan usaha mereka. Karyawan yang termasuk kelompok external control, akan merasa bahwa kinerja mereka diluar usahanya, mereka merasa bahwa banyak faktor dari luar (eksternal) yang mempengaruhi kinerja mereka. (Luthans, 1995 dalam (Restuningdiah, 2004).
Penelitian ini sejalan dengan hasil penelitian terdahulu (Nugrahaningsih, R, dkk, 2013), menyatakan bahwa locus of control Internal paling berpengaruh terhadap komitmen organisasi dan (Kamasanti, 2008) menemukan terdapat hubungan dalam kategori sedang dan signifikan antara locus of control dengan komitmen organisasi.

Sebagian besar perawat dengan Internal locus of control memiliki komitmen afektif yang tinggi (87\%) dan komitmen normatif yang tinggi $(84.8 \%)$. Hal ini sesuai dengan pendapat Coleman, Irving dan Cooper (1999) dalam Herlina D.S (2011), bahwa Internal locus of control berhubungan dengan komitmen afektif. Hasil penelitian lain menemukan karyawan dengan internal locus of control memiliki komitmen organisasi yang tinggi dibandingkan dengan eksternal lokus of control. (Noviarini \& Saroyeni, Peran Locus of Control dalam Hubungan Job Insecurity dengan Komitmen Organisasi dan Kepuasan Kerja, 2013). Sedangkan hasil penelitian (Chen \& Wang, 2007) internal locus of control berasosiasi dengan komitmen afektif dan komitmen normatif. Hal ini menunjukkan bahwa seseorang dengan internal locus of control memiliki komitmen organisasi karena memang menginginkan bergabung dalam organisasi tersebut atau berpendapat bahwa loyal terhadap organisasi merupakan suatu kewajiban. Individu dengan Internal locus of control merupakan aset yang penting bagi perusahaan karena tipe seperti ini akan memberikan kontribusi yang sangat besar terhadap organisasi. Sebaliknya terdapat individu dengan internal locus of control (41.3\%) yang memiliki komitmen berkelanjutan yang tinggi.

Hal ini menunjukkan bahwa masih ada beberapa perawat yang salah satu motivasinya loyal terhadap organisasi adalah karena tidak mendapatkan pekerjaan di tempat lain dan 
karena membutuhkan gaji dari organisasi. Individu dengan komitmen berkelanjutan yang tinggi, patut diwaspadai karena sewaktu-waktu dapat meninggalkan organisasi jika mendapat peluang yang lebih besar ditempat lain atau jika imbalan yang diterima tidak sesuai dengan yang diharapkan. Temuan ini sesuai dengan teori bahwa salah satu upaya untuk meningkatkan komitmen karyawan adalah dengan cara memenuhi apa yang menjadi harapan karyawan (Buchanan, 1975 dalam (Djati, 2003). Sementara menurut (Steers \& Potter, 1983), bahwa salah satu cara meningkatkan kepuasan karyawan adalah dengan memberikan kompensasi yang memuaskan. Jadi individu dengan komitmen berkelanjutan yang tinggi jika harapannya tidak sesuai dengan kenyataan, maka dapat menurunkan komitmennya terhadap organisasi.

\section{KESIMPULAN DAN SARAN}

Ada hubungan yang bermakna antara locus of control dengan komitmen organisasi perawat. Hendaknya manajemen mengembangkan komitmen organisasi pada diri individu terutama affectif komitmen dan normatif komitmen, karena anggota organisasi yang memiliki komitmen yang tinggi akan mempertahankan keangotaannya, sekaligus akan berusaha keras atas nama organisasi dan akan memberikan kontribusi positif terhadap pencapaian organisasi. Penelitian lanjutan terhadap variabel organisasi untuk memperkuat penelitian ini.

\section{DAFTAR PUSTAKA}

Adolfina. (2012). Locus of Control dan Kemampuan sebagai Determinan Kepuasan, Komitmen Organisasi dan Kinerja Perawat Rumah Sakit di Kota
Manado. Makassar: Pascasarjana Universitas Hasanuddin.

Ayudiati, S. (2010). Pengaruh Locus of Control terhadap Kinerja dengan Etika Kerja Islam sebagai variabel Moderating pada Bank Jateng Semarang. Bandung: Fakultas Ekonomi Universitas Diponegoro.

Chen, \& Wang. (2007). Locus of Control and The Three Components of Commitment to Change. Personality and Individual Differences, 503-512.

Djati, S. (2003). Kajian terhadap Kepuasan Kompensasi, Komitmen Organisasi, dan Prestasi Kerja . Jurnal Manajemen dan Kewirausahaan Vol. 5 No. 1, 25-41.

Kamasanti, T. (2008). Hubungan Locus of Control dengan Komitmen Organisasi pada Karyawati yang Berumah Tangga di PT. X Tangerang. Jurnal Psikologi Vol.6.

Notoatmodjo, S. (2010). Metodologi Penelitian Kesehatan. Jakarta: Rinike Cipta.

Nugrahaningsih, R, dkk. (2013). Pengaruh Locus of Control Internal dan Eksternal Terhadap Komitmen Dokter di RSUD Abdul Wahab Sjahranie Samarinda. Makassar : Pasca Sarjana Universitas Hasanuddin.

Restuningdiah, N. (2004). Pengaruh Locus of Control terhadap Hubungan Komitmen Profesional dan Kepuasan Kerja Akuntan Pendidik. Malang: Fakultas Ekonomi Universitas Negeri Malang.

Rotter, J. (1966). Generalized Expectancies for Internal Versus External Control of Reinforcement. Psychological Monographs, 80.

Steers, R., \& Potter, L. (1983). Motivation and Work Behavior. New York: Academic Press. 